\title{
Arte e direito: A Justiça, de Alfredo Ceschiatti, no STF
}

\author{
Art and Law: the Ceschiatti's statue of Justice in the Supreme Court of \\ Brazil
}

Arte y derecho: la Justicia de Ceschiatti en el Supremo Tribunal Federal

\author{
Rafael Lazzarotto Simioni ${ }^{2}$ \\ Faculdade de Direito do Sul de Minas (Pouso Alegre, MG, Brasil) \\ ORCID: https://orcid.org/0000-0002-8484-4491 \\ E-mail: simioni2010@gmail.com
}

\section{Resumo}

Esta pesquisa objetiva propor uma interpretação jurídica da estátua $A$ Justiça, de Alfredo Ceschiatti, para o prédio do Supremo Tribunal Federal. Trata-se de uma imagem inovadora na história da arte, que estabelece um diálogo profundo entre força, justiça e direito. Para tanto, como método, esta investigação parte de três chaves de leitura: a) a relação de Ceschiatti com a estética do movimento concretista na história da arte do Brasil dos anos de 1950 e 1960; b) a relação entre presença, ausência e o espaço arquitetônico para o qual a obra foi pensada; e c) o diálogo entre auctoritas e potestas, que permite interpretar a espada no colo e a ausência da balança como um convite à participação do observador. Como resultado, A Justiça de Ceschiatti é uma justiça da autonomia, que articula de modo surpreendente a tensão histórica entre força, justiça e direito.

\section{Palavras-chave}

Arte; Direito; Justiça; Alfredo Ceschiatti; Supremo Tribunal Federal.

\footnotetext{
SIMIONI, Rafael Lazzarotto. Arte e direito: A Justiça, de Alfredo Ceschiatti, no STF. Suprema: revista de estudos constitucionais, Brasília, v. 1, n. 2, p. 221-255, jul./dez. 2021.

2 Pós-Doutor em Filosofia e Teoria do Direito pela Universidade de Coimbra, Doutor em Direito Público pela Unisinos, Mestre em Direito pela UCS, Professor Titular do PPGD/FDSM e PPGEducs/Univás. Coordenador do Programa de Pós-Graduação em Direito da FDSM. Professor Convidado do Programa de Pós-Graduação em Educação da Unicamp e da Pós-Graduação em Direitos Fundamentais da Unicamp. Pesquisador-Líder do Grupo de Pesquisa Margens do Direito e do Grupo de Pesquisa Arte e Direito (CNPq). É autor de artigos e livros na área de hermenêutica jurídica, teoria do direito e história do direito. Currículo Lattes: http://lattes.cnpq.br/0651879354342863.
} 


\section{Suimário}

1. Introdução. 2. O limiar entre arte, política e direito. 3. Justiça, guerra e sabedoria. 4. Justiça sentada ao lado direito de Júpiter. 5. Justiça cega. 6. Espada sem sombras. 7. O vazio da balança. 8. Conclusão.

\section{Abstract}

This research proposes a legal interpretation of Alfredo Ceschiatti's statue of Justice for the Supreme Federal Court building, Brazil. The statue is innovative in art history, which establishes a profound dialogue between power, justice and law. Therefore, this investigation starts from three keys of reading: a) Ceschiatti's relationship with the concretist phase of art history in Brazil in the 1950s and 1960s; b) the relationship between presence, absence and the architectural space for which the work was designed; and c) the dialogue between auctoritas and potestas, which makes it possible to interpret the sword and the absence of the scales not as omission, but as a invitation to the participation in the image. As a result, Ceschiatti's justice is a justice of autonomy, which articulates the historical tension between power, justice and law.

\section{Keywords}

Art; Law; Justice; Alfredo Ceschiatti; Supreme Court of Brazil.

\section{Contents}

1. Introduction. 2. The threshold between art, politics and law. 3. Justice, war and wisdom. 4. Justice and Jupiter. 5. Blind Justice. 6. Sword without shadows. 7. Justice without scale. 8 . Conclusion.

\section{Resumen}

Esta investigación propone una interpretación jurídica de la estatua de la Justicia de Alfredo Ceschiatti para el edificio del Supremo Tribunal Federal, Brasil. Es una imagen innovadora en la historia del arte, que establece un diálogo profundo entre fuerza, justicia y derecho. A investigación parte de tres claves de lectura: a) La relación de Ceschiatti con la fase concretista de la historia del arte en Brasil en las décadas de 1950 y 1960; b) la relación entre presencia, ausencia y el espacio arquitectónico para el que se pensó la obra; y c) el diálogo entre auctoritas y potestas, que permite interpretar la espada y la ausencia de escala no como formas de omisión, sino como una cuidadosa invitación a la participación del observador. En consecuencia, la justicia de Ceschiatti es una justicia de autonomía, lo que sorprendentemente articula la tensión histórica entre fuerza, justicia y derecho. 


\section{Palabras clave}

Arte; Derecho; Justicia; Alfredo Ceschiatti; Supremo Tribunal Federal.

\section{Índice}

1. Introducción. 2. El umbral entre arte, política y derecho. 3. Justicia, guerra y sabiduría. 4. Justicia sentada al lado derecho de Júpiter. 5. Justicia ciega. 6. Espada sin sombras. 7. El vacío de la balanza. 8. Conclusión.

Figura 1 - A Justiça (1961), de Alfredo Ceschiatti. Supremo Tribunal Federal

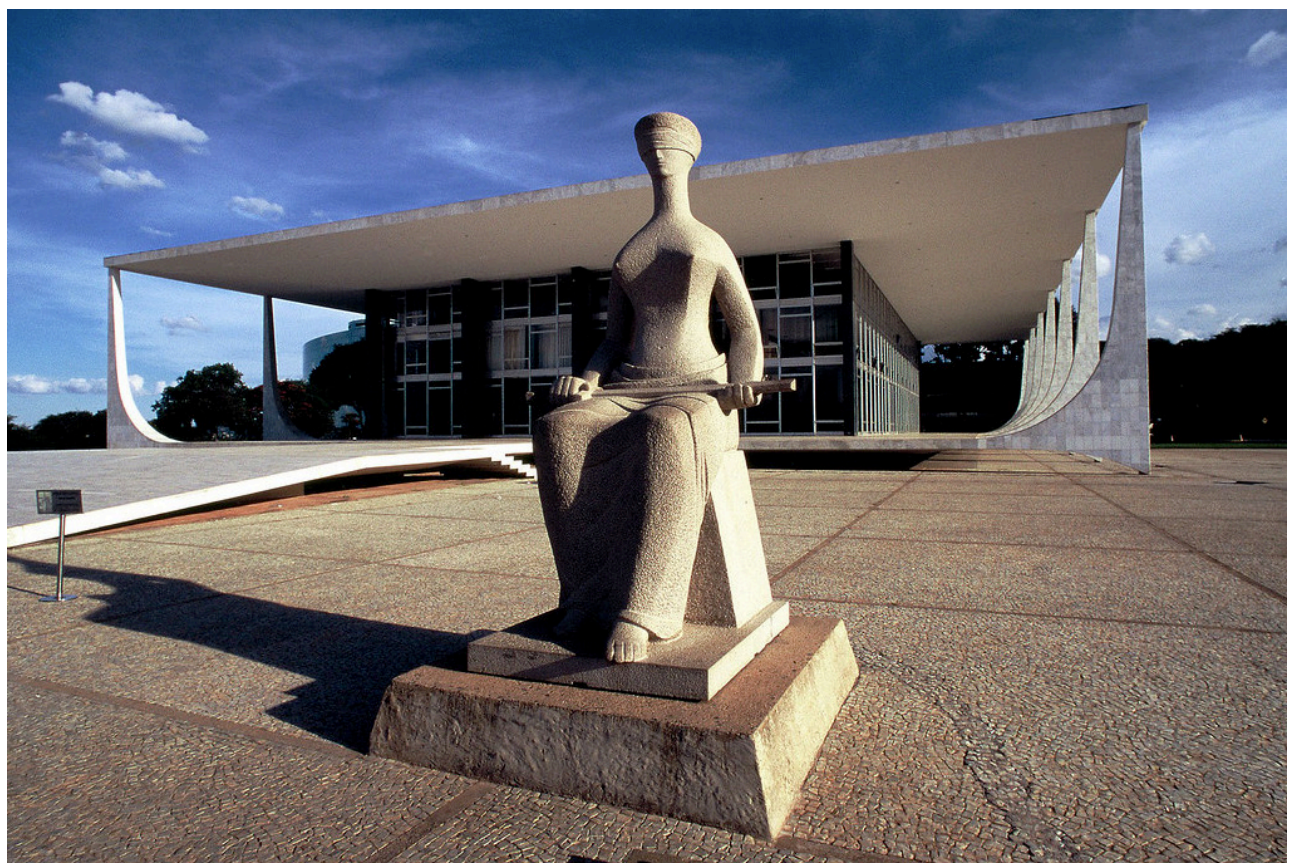

Fonte: DIEHL, Jorge. A Justiça. 2009. 1 fotografia. Acervo pessoal do artista. Publicação com autorização do artista.

\section{Introdução}

Podemos observar uma estátua da Justiça e compreender seu significado pelo que ela tem: espada, balança, venda nos olhos, corpo feminino. Mas também podemos entendê-la pelo que lhe falta, pelos objetos dela ausentes. Os escultores renascentistas de Florença apresentaram ao mundo um outro modo de ver e compreender estátuas (WARBURG, 2013, p. 428). Introduziram uma relação especial com a temporalidade da obra. Artistas como Da Vinci, Rafael e 
Michelangelo revolucionaram a história das artes visuais, situando suas obras não apenas na conexão entre objetos, mas também na relação com o tempo.

O Davi, de Michelangelo, é um exemplo dessa revolução artística. Ela retrata a cena bíblica em que o jovem Davi, futuro rei de Israel, enfrenta o gigante Golias, campeão dos filisteus. Mas onde estão, na estátua de Michelangelo, Golias, o Rei Saul, os exércitos, as armas? Michelangelo esculpiu o jovem Davi no momento que antecede à batalha com Golias. É o momento em que ele caminha, com a nudez da sua vida exposta, em direção à batalha com o perigoso Golias, carregando apenas, sobre o ombro esquerdo, a funda com a qual arremessará a pedra que derrubará Golias com o rosto ao chão.

A estátua A Justiça (DIEHL, 2009), construída por Alfredo Ceschiatti para o prédio do Supremo Tribunal Federal (STF), é uma representação artística desse tipo. Ela não marca a completude de uma relação entre objetos, mas sim uma temporalidade. Renunciando à completude dos seus elementos tradicionais, $A$ Justiça de Ceschiatti simboliza uma ação, um fazer, uma dinâmica inscrita em uma relação com o tempo. Davi sem Golias, Justiça sem balança. Davi carregando a funda confortável e confiantemente sobre seu ombro esquerdo; Justiça sentada, guardando a espada em seu colo.

A Justiça de Ceschiatti fala de uma temporalidade específica da Justiça. Não é o momento da ponderação, porque ela está sem balança. Também não é o tempo da sanção soberana, porque a espada não se encontra bramida em sua mão, e sim descansando, confortavelmente, em seu colo. A posição de seus pés, em contrapeso, fala que ela está pronta para se levantar - ou que acabou de se sentar. Talvez como o Davi de Michelangelo, A Justiça de Ceschiatti encontra-se esculpida no tempo imediatamente anterior ao da ação principal, que é o da realização da justiça.

Mas onde está a balança da ponderação? Por que Ceschiatti escolheu esculpir uma Justiça vendada, já que, na história da arte, a venda nos olhos é uma característica apenas da modernidade? Por que ela está confortavelmente sentada em um trono na capital de um país com índices brutais de desigualdade social? À primeira vista, A Justiça de Ceschiatti poderia parecer uma figura tola, se comparada com a simbologia de outras Justiças modernas e contemporâneas. Poderia também ser vista como uma imagem abstrata, alienada e isolada em um imaginário político absolutamente desconectado da realidade social brasileira, que convive com uma falta de justiça social que exigiria, no mínimo, uma Justiça 
de pé. Por trás dessa aparência, a estátua esconde uma complexa rede de relações simbólicas que pretendemos analisar nesta investigação.

Esta pesquisa faz parte do projeto Imagens da Lei, do Grupo de Pesquisa Margens do Direito (PPGD/FDSM), que procura realizar releituras jurídicas de importantes obras de artes visuais sobre o direito. Nesta investigação, queremos propor uma discussão jurídica da estátua $A$ Justiça realizada por Alfredo Ceschiatti para o prédio do STF. Trata-se de uma tarefa desafiadora, porque não há suficientes referências bibliográficas sobre Ceschiatti. Não há registros - ou eles estão bem escondidos - sobre a intencionalidade de Ceschiatti sobre a sua Justiça. Não sabemos sequer o conceito de Justiça do artista ou suas referências. Também desconhecemos a relação que o artista tinha com o direito ou com a política da sua época. Sabemos apenas que ele não tinha uma relação significativa com o direito e que sua obra flerta com o barroco clássico e com a linguagem da fase concretista do modernismo brasileiro dos anos de 1950 e 1960.

Felizmente, do mesmo modo que não interpretamos o direito vinculado à intenção do legislador, também não interpretamos obras de arte vinculadas à intenção do artista. Uma obra, quando apresentada ao público, escapa das mãos do seu criador. Seu sentido se transforma. Seu significado se conecta a uma rede histórica de relações de significação que já não depende mais do artista. A relação entre seus elementos já não é mais comandada pelos próprios elementos ou pela unidade metafísica da intenção do artista. Uma obra, uma vez publicada, passa a se inscrever na história de relações de significados que ela mesma não controla.

No que segue, pretende-se propor uma leitura jurídica da estátua A Justiça de Alfredo Ceschiatti. Para tanto, utilizaremos três chaves de leitura: a) a relação de Ceschiatti com o movimento artístico concretista dos anos de 1950 e 1960 na história da arte do Brasil; b) a relação entre presença, ausência e o espaço arquitetônico para o qual a obra foi pensada; e c) a relação entre auctoritas e potestas, que se encontra presente na fundação mitológica das imagens da justiça desde a relação entre Osíris e Maat no antigo Egito, Zeus e Themis na Grécia e Júpiter e Justiça em Roma. O diálogo entre auctoritas e potestas permite interpretar a espada no colo da Justiça não como uma omissão, mas como uma cuidadosa ação política, especial e surpreendente para a cultura das democracias constitucionais. A ausência da balança também poderá ser entendida, a partir dessas chaves de leitura, como um convite à participação do observador. 
Para serem alcançados esses resultados, a metodologia utilizada é a observação de segunda ordem da teoria dos sistemas sociais (LUHMANN, 2005, p. 102), a qual permite entender a observação como uma forma de distinção entre o sentido indicado/distinguido e o restante das potencialidades de sentido que, depois da distinção, ficam como um pressuposto implícito de significação. É um modo de observação que, entre outras coisas, trabalha no nível dos paradoxos da auto-observação, do paradoxo de observar a justiça em nós mesmos. Talvez a balança não esteja com a Justiça porque ela deve estar em nós; e a venda nos olhos, mais do que o símbolo da imparcialidade, pode significar a importância de estarmos atentos e vigilantes, com os olhos bem abertos, para as injustiças sociais que carregamos em nossa história.

Nossa hipótese é a de que Ceschiatti, de modo inteligente, deslocou elementos que definem a identidade da Justiça para demonstrar que a verdadeira justiça não está em uma divindade ou em uma dimensão mítico-metafísica, mas, sim, dentro do prédio do STF, na atuação dos Ministros e em nós mesmos. A Justiça está sentada justamente porque quem deve estar de pé somos nós. Ela não tem balança porque a balança da proporcionalidade deve estar em nós. Ela é cega para nos lembrar de estarmos com os olhos bem abertos. Sua forma estilizada, geometrizada, não humana, afirma que a justiça, em uma prática jurídica concreta, somente pode ser realizada por nós.

\section{O limiar entre arte, política e direito}

Alfredo Ceschiatti foi um escultor brasileiro do século 20, conhecido por suas esculturas nos principais prédios públicos de Brasília. Mas o artista dos espaços políticos mais importantes da República é, paradoxalmente, pouco conhecido em sua vida privada e em suas referências intelectuais ou culturais. Pessoa reservada, Ceschiatti deixou poucos escritos, realizou poucas exposições, concedeu poucas entrevistas. Mas sua genialidade, como tentaremos explicitar nessa pesquisa, não é uma marca acidental, aleatoriamente inscrita em uma ou outra de suas estátuas. Pelo contrário, sua obra possui uma fina coerência com sua trajetória artística, sutileza em sua potência significativa e complexidade entre seus elementos.

A Justiça (DIEHL, 2009) de Ceschiatti é uma estátua construída para simbolizar a Justiça do Brasil. Presentifica a imagem daquilo que o Brasil tem como um conceito importante de Justiça naquele período histórico. Esculpida em um 
bloco maciço de granito, a estátua não foi pensada para ser apenas um enfeite ou um objeto de decoração do prédio do STF. Uma estátua modernista pode ser qualquer coisa, menos uma simples representação ornamental de figuras clássicas (BRITO, 1971, p. 29; FABRIS, 1994, p. 15; SIMIONI, 2014, p. 233). É uma obra de arte cuja leitura desafia o olhar a enxergar para além da obviedade de suas formas e elementos. A sutileza da relação entre os seus elementos e o espaço arquitetônico para o qual ela foi pensada produz uma potência de significação que pode influenciar a imagem que nós temos da justiça no Brasil.

Os símbolos ou elementos que faltam em suas obras constituem interessantes chaves de leitura. E não se trata apenas da estátua $A$ Justiça. Uma rápida visão de conjunto permite observar isso desde suas primeiras esculturas. O abraço (O ABRAÇO, 2015) sem braços na Lagoa da Pampulha, em Belo Horizonte; As três Forças Armadas (Rctk caRIOca, 2011) sem armas no Monumento Nacional aos Mortos da Segunda Guerra Mundial, no Rio de Janeiro; a Minerva (JUNIOR; MORENO, 2019b) sem capacete e escudo de guerreira na Biblioteca da Universidade de Brasília (UnB); uma contorcionista no lugar das máscaras da comédia e da tragédia no Teatro Nacional de Brasília; e A Justiça (DIEHL, 2009) sem balança no prédio do STF. Como observou Didi-Huberman (2013, p. 136), os fantasmas são os que, por sua rebeldia, sobrevivem em uma cultura. As ausências nas esculturas de Ceschiatti falam mais alto do que as presenças, e, precisamente nesta relação, podemos encontrar a sutileza da sua singularidade.

Um artista como Ceschiatti não constrói uma obra por acaso. Ele não deixa de fora elementos-chave de seus personagens por razões estéticas ou mesmo por questões ligadas às limitações dos materiais utilizados na construção das esculturas. Escultores experientes sabem que granito pode facilmente lascar, e, talvez, para não correr o risco de estragar o bloco maciço, trazido da região de Petrópolis, no Rio de Janeiro, poderia muito bem o escultor decidir não fazer a balança, porque o granito é uma pedra muito dura que não permite objetos com detalhes finos, como é o caso de uma balança. Também se poderia pensar que, para uma estátua a ser instalada em área externa, exposta ao sol, chuva e intempéries, é importante evitar formas capazes de acumular água, poeira ou substâncias que, com o tempo, produziriam manchas e até corrosões no material. Hipóteses plausíveis, mas não. Há várias formas de se esculpir uma balança no granito e Ceschiatti saberia como fazê-lo. As ausências nas suas esculturas são sutis formas de dizer algo especial. Modos inteligentes de disparar a produção de novos sentidos sobre formas clássicas. 
Uma obra de arte visual, como a estátua $A$ Justiça de Ceschiatti, é uma forma de discurso pictórico sobre a relação entre direito, força e poder. É um diálogo entre imagem e imaginação, que constrói um imaginário a respeito do direito. A arte, assim, não apenas é um poderoso meio de confirmação dos valores políticos hegemônicos de cada época, mas também é um poderoso meio de ruptura, crítica e subversão desses valores. Quando vemos uma estátua da Justiça, podemos ver tanto os elementos que reafirmam os valores iluministas burgueses de imparcialidade, racionalidade e abstração, quanto as relações críticas que o artista estabeleceu justamente para questionar esses valores. O diálogo entre os elementos que o artista relacionou - e os que ele não relacionou, mas poderia ter relacionado - dispara uma potencialidade de significações sem precedentes.

Com o projeto de construção de Brasília, Ceschiatti tornou-se um dos principais escultores de diversas obras em importantes prédios públicos da capital. Suas estátuas são finos diálogos entre arte, arquitetura e política. São imagens que dialogam com o imaginário político do Brasil da época. Mas não se trata de meros correlatos visuais das políticas desenvolvimentistas do governo de Juscelino Kubitschek. As obras de Ceschiatti são críticas, questionadoras, rebeldes. Em todas elas há um jogo entre ausências e presenças que, no ambiente arquitetônico para o qual foram pensadas, produz um significado particular surpreendente.

Como um correlato visual dos discursos políticos da modernização e do desenvolvimento econômico do Brasil, o conceito arquitetônico de Brasília construiu a imagem de um centro do poder dominado pela racionalidade, objetividade e sobriedade. Prédios distantes entre si constituem a antítese à cultura política do patrimonialismo brasileiro, que pressupõe formas de ocupação mais intimistas dos espaços públicos. Linhas e formas geometrizadas afirmam o domínio da razão superando o domínio da subjetividade e da pessoalidade no tratamento dos assuntos políticos. A arquitetura não é uma questão apenas de funcionalidade das formas de ocupação dos espaços, mas também uma forma de poder. Um modo de confirmar um regime de verdade sobre os modos de ocupação dos espaços. Nesse sentido, uma disputa entre projetos arquitetônicos sempre é uma disputa política.

Observar a conexão que Ceschiatti estabelece entre o significado da sua obra e o ambiente no qual ela é instalada é uma chave importante para a interpretação de seu conceito artístico. Do mesmo modo que a representação do Livro do Gênesis no ambiente do batistério é o que tornou seus painéis geniais na Igreja da Pampulha (GUEDES; VIVAS, 2016, p. 916), também a relação entre 
As Iaras (AS IARAS, [19--?]) e o lago do Palácio da Alvorada é o que completa o significado da obra - tanto que é comum referir-se a essa obra como "as banhistas". A representação de duas figuras femininas na residência oficial do Governo Executivo, que, na tradição da cultura europeia, é o lugar-símbolo da força do poder soberano, constitui uma profunda revisão dos arquétipos do imaginário político. Na entrada da morada do chefe do Governo Executivo, duas mulheres tomando banho em uma relação intimista e delicada, tranquilas, relaxadas, como se se sentissem seguras e confiantes.

As Iaras (AS IARAS, [19--?]) são uma antítese à imagem mítica do Executivo como o poder soberano de morte e de guerra. Uma antítese à tirania. Elas falam de um soberano cuidadoso, detalhista, flexível, acolhedor e fraterno, que é o contrário do arquétipo tradicional do soberano como expressão do idealismo masculino da força, da ordem e da abstração, que se encontra na tradição ocidental desde as figuras de Utu na mitologia suméria, Shamash na babilônica, acádia e assíria, Osíris na egípcia, Salomão na hebraica, Zeus na grega ou Júpiter na romana. Na linha do modernismo brasileiro da época, Ceschiatti poderia ter construído, para simbolizar o poder soberano no Brasil, a estátua masculinizada de um índio forte e altivo, com arco e flecha na mão e acompanhado de uma onça, uma arara e um sagui agarrado ao ombro. Havia bons motivos, naquela época, para utilização dessa simbologia pitoresca do Brasil nativo nos espaços políticos. Mas duas mulheres tomando banho, em uma relação fraterna e de absoluta confiança entre elas constroem e legitimam outra imagem do poder soberano do Brasil. 
Figura 2 - As Iaras (1960), de Alfredo Ceschiatti. Palácio da Alvorada

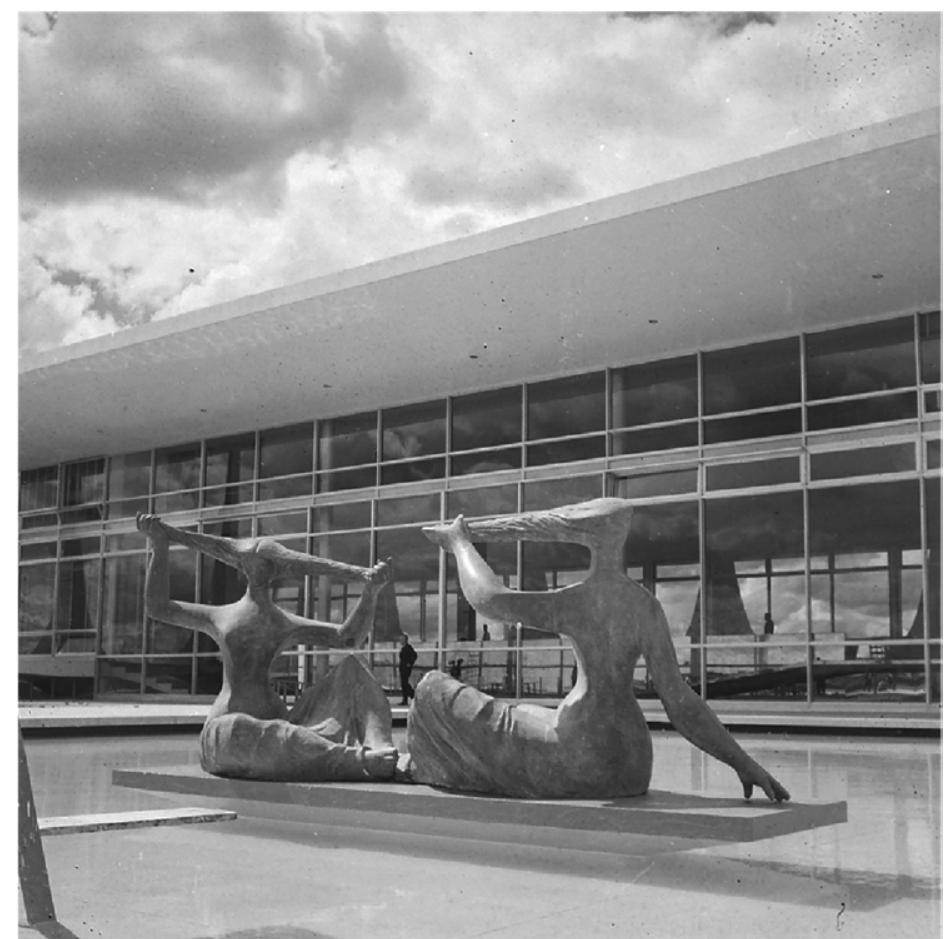

Fonte: AS IARAS. [19--?]. 1 fotografia. Disponível em: https://pt.m.wikipedia.org/wiki/Ficheiro:Obra_\%22As_ Iaras\%22_de_Alfredo_Ceschiatti.jpg. Acesso em: 26 abr. 2021.

Do mesmo modo, as Duas amigas (DUAS..., [19--?]) no Palácio do Itamaraty ganham outro sentido quando as observamos no contexto do lugar no qual elas foram instaladas. Afinal, o Itamaraty é o lugar de encontro entre os chefes de Estado de diferentes países. O lugar dos negócios internacionais, da diplomacia, da construção de alianças e acordos, do cultivo da amizade entre os Estados. A beleza das Duas amigas (DUAS..., [19--?]) adquire uma riqueza de significação explosiva quando observada no espaço arquitetônico - que também é um espaço político - para o qual a obra foi pensada pelo artista. 
Figura 3 - Duas Amigas (1960), de Alfredo Ceschiatti. Palácio do Itamaraty

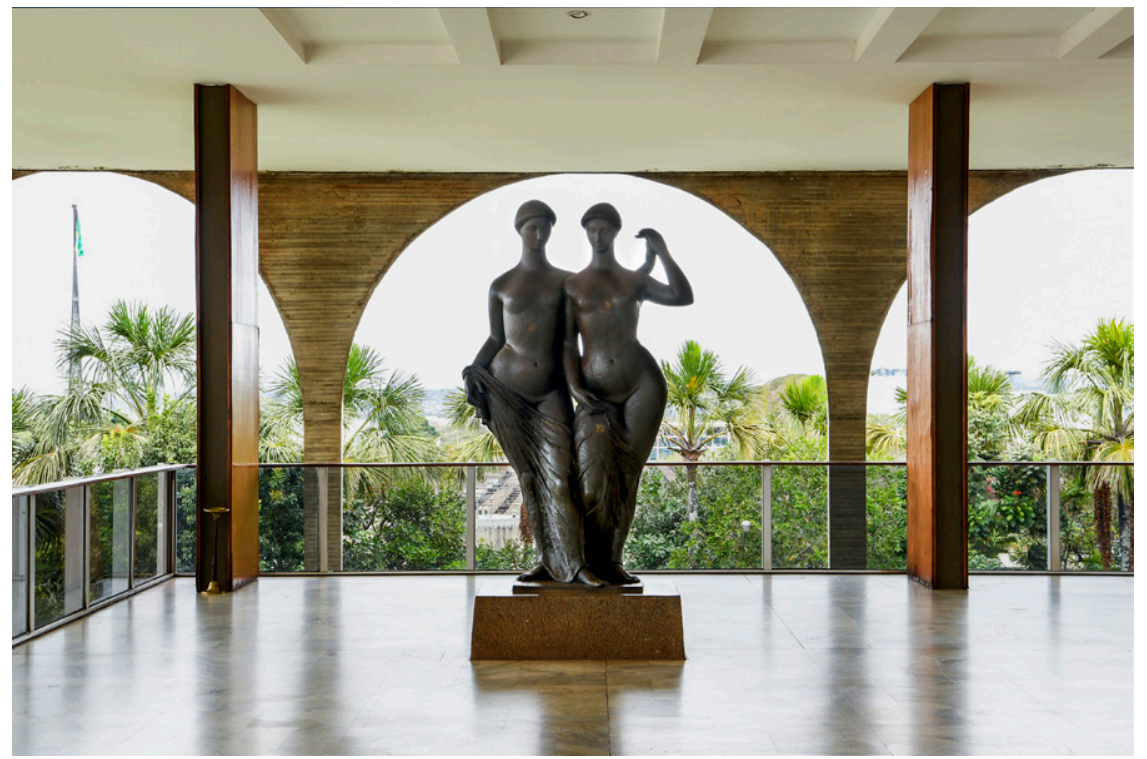

Fonte: DUAS amigas. [19--?]. 1 fotografia. Disponível em: https://www.gov.br/mre/pt-br/media/dsc0113-dammer. jpg/view. Acesso em: 26 abr. 2021.

Esse conceito de obra de arte que dialoga com o ambiente arquitetônico para o qual foi pensada também pode ser observado nos quatro Evangelistas (JUNIOR; MORENO, 2019a) esculpidos por Ceschiatti para a área externa da Catedral de Brasília. Estátuas verticalizadas parecem corpos esticados para o céu, que convidam o olhar a participar do ambiente arquitetônico inteiro, em sua plenitude sensorial. Se comparadas com os volumes horizontais da estátua As Iaras (AS IARAS, [19--?]) do Palácio da Alvorada ou das Duas amigas (DUAS..., [19--?]) do Palácio Itamaraty, os Evangelistas (JUNIOR; MORENO, 2019a) possuem volumes verticais. É outro modo de organização da forma de ocupação dos espaços arquitetônicos. As figuras horizontais denotam equilíbrio, força, segurança, solidez, enquanto as verticalizadas denotam dinâmica, velocidade, movimento. É como se os Evangelistas (JUNIOR; MORENO, 2019a) convidassem o observador a caminhar por entre eles para ver o conjunto inteiro da obra e experimentar o domínio da fé.

Esse jogo entre volumes horizontais e verticais talvez não seja diferente da estátua $A$ Justiça (DIEHL, 2009) do STF: um conceito artístico pensado para dialogar com o ambiente arquitetônico no qual ela está inserida, combinando o equilíbrio e a força do pesado trono no qual ela se encontra sentada, mas ao 
mesmo tempo verticalizada por meio de um dorso e pescoço exageradamente esticados, de modo a denotar dinamismo, movimento e agilidade. Combinada com a posição das suas pernas em contrapeso e com o pé esquerdo apoiado para fora da base, a figura da Justiça parece estar pronta para se levantar a qualquer momento. Uma paradoxal combinação de elementos de equilíbrio, força e peso com dinamismo, movimento e agilidade.

O pé para fora da base, que produz a sensação de que a estátua pode saltar da sua base estática e invadir nosso mundo, é uma técnica renascentista, utilizada por Michelangelo na estátua de Davi e pode ser observada também na estátua neoclássica da deusa Minerva no Portão de Brandemburgo em Berlin. Com essa técnica, o artista criou uma Justiça que se situa no limiar entre estática e movimento. Uma estátua que se move entre o mundo dos objetos e o nosso mundo.

Mas, para além do jogo entre as formas estéticas, também há, em um nível mais profundo de observação, uma sofisticada dialética entre arte, arquitetura e política. São diferentes formas de legitimação do discurso político da modernização e do desenvolvimentismo daquele período histórico. Elas produzem eloquência visual sobre aqueles fundamentos e valores políticos. As obras de Ceschiatti em Brasília são diferentes modos de equacionar, na dimensão do visual, a tensão histórica entre direito, força e poder.

\section{Justiça, guerra e sabedoria}

Do ponto de vista formal, Ceschiatti foi um artista despreocupado em se manter em constante diálogo com os movimentos artísticos de sua época. O estilo geometrizado e tipicamente concretista da estátua $A$ Justiça (DIEHL, 2009) não se encontra presente em todas as suas obras. Há elementos formais em comum, que definem a sua identidade estética, mas não é uma obra, em seu conjunto, coerente com algum movimento artístico em particular.

Destacam-se as Duas amigas (DUAS..., [19--?]), também conhecidas como as Duas irmã s, esculpidas em 1966 para o Salão Nobre do Palácio Itamaraty, e As Iaras (AS IARAS, [19--?]), vulgarmente conhecidas como “as banhistas”,

\footnotetext{
3 Segundo Ceschiatti, a estátua Duas irmãs ou Duas amigas (DUAS..., [19--?]) construída para o Palácio Itamarty foi inspirada no filme Persona, de Ingmar Bergman (MÃOS..., 1976, p. 108), que narra a história de uma atriz que fica muda após sofrer um trauma ao interpretar a personagem Electra da obra de Sófocles.
} 
construídas em bronze para o lago do Palácio da Alvorada. Nessas duas obras já aparece o estilo do artista, como pescoços alongados e formato triangular das cabeças, que estará presente também na estátua A Justiça (DIEHL, 2009). Mas os corpos fornidos, em poses que acentuam as curvas, parecem ainda dialogar com uma referência barroca. Há um flerte com o barroco nelas. A Justiça não tem nada disso.

A Justiça (DIEHL, 2009) apresentará uma ruptura com essa estética. Embora ela tenha sido esculpida logo após As Iaras (AS IARAS, [19--?]) do Palácio da Alvorada e antes de Duas amigas (DUAS..., [19--?]) do Palácio Itamaraty (MÃOS..., 1976, p. 108), A Justiça (DIEHL, 2009) será construída de um modo totalmente geometrizado, abstrato, racionalizado. Diferente dAs Iaras (AS IARAS, [19--?]) e das Duas amigas (DUAS..., [19--?]), A Justiça (DIEHL, 2009) assumirá uma estética que estava presente em uma obra anterior de Ceschiatti, que é As três Forças Armadas (Rctk caRIOca, 2011), de 1960, esculpida para o Monumento Nacional aos Mortos da Segunda Guerra Mundial, no Rio de Janeiro.

Figura 4 - As três Forças Armadas (1960), de Alfredo Ceschiatti

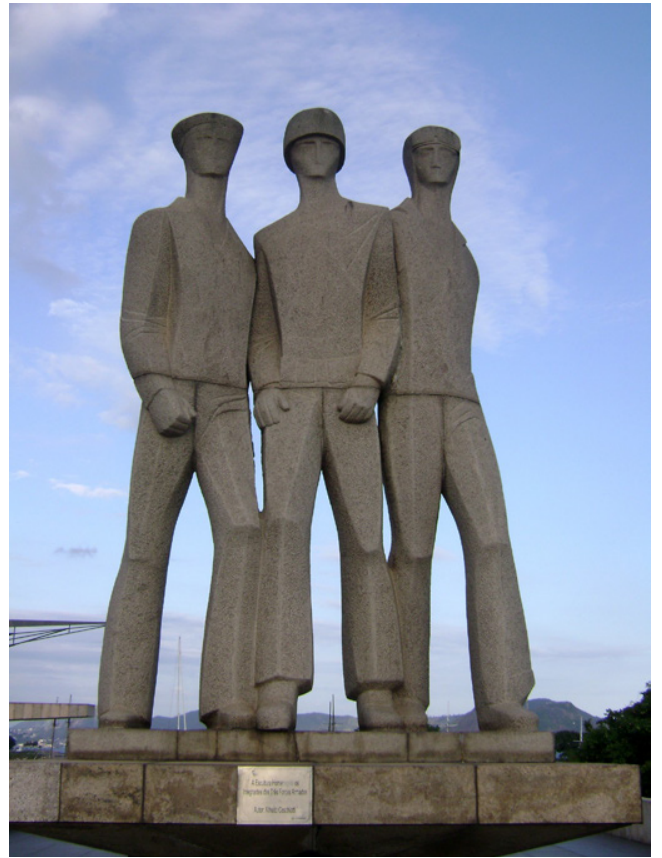

Fonte: Rctk CaRIOca. As três Forças Armadas. 2011. 1 fotografia. Reprodução com autorização do autor. 
As três Forças Armadas (Rctk caRIOca, 2011) não possuem armas, como $A$ Justiça (DIEHL, 2009) sem balança ou Minerva (JUNIOR; MORENO, 2019b) sem escudo e capacete de guerreira. É uma forma inteligente de simbolizar a unidade das forças armadas: sem armas, os três homens olham para o mesmo lugar. $\mathrm{O}$ que os diferencia é apenas o quepe da Aeronáutica, o capacete do Exército e o bibico da Marinha. Eles têm um mesmo e único objetivo, independentemente das diferenças entre as armas.

As linhas geometrizadas dialogam com o movimento concretista dos anos 1950 a 1960. E uma referência visual que lembra esse estilo de construção das linhas em As três Forças Armadas (Rctk caRIOca, 2011) e A Justiça (DIEHL, 2009) podemos encontrar, como percebeu Silva (2019, p. 34), em Cândido Portinari, que foi professor de Ceschiatti e, provavelmente, uma de suas referências. Observam-se a pesquisa e exploração dos volumes nos antebraços e nas panturrilhas dos corpos de Portinari e, comparem-se com os das estátuas de Ceschiatti. Ambos apresentam semelhantes "exageros" de volume, que criam uma identidade visual que os aproxima.

Figura 5 - O lavrador de café (1934), de Cândido Portinari. Óleo sobre tela

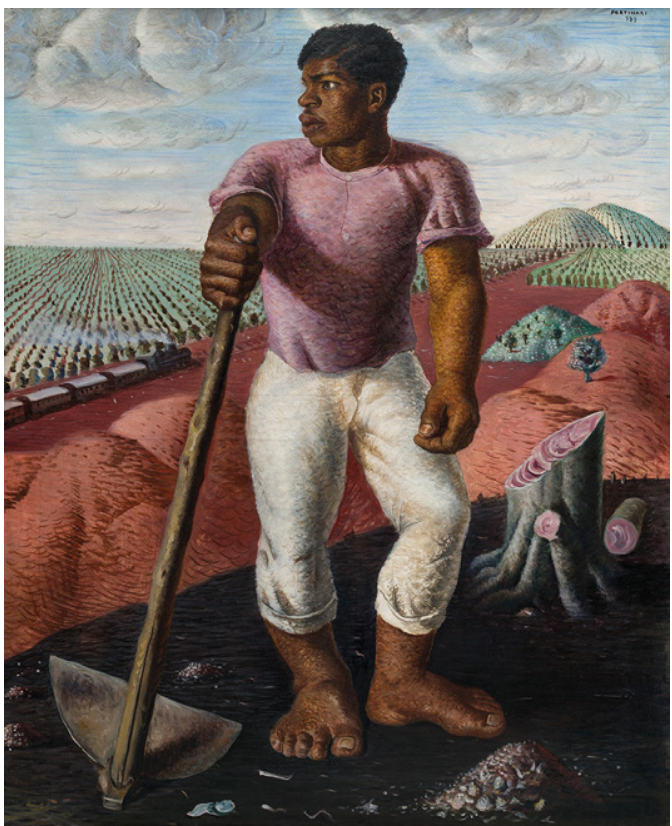

Fonte: MUSA, João. O lavrador de café. [19--?]. 1 fotografia. Disponível em: https://masp.org.br/acervo/obra/olavrador-de-cafe. Acesso em: 26 abr. 2021. 
Portinari foi pintor, Ceschiatti escultor. Portinari pintava o homem do povo e as cenas do cotidiano. Ceschiatti esculpia temas clássicos e universalistas. Mas, se comparamos a dramaticidade dos pés e das mãos de Portinari com os pés e as mãos dos Evangelistas (JUNIOR; MORENO, 2019a) da Catedral de Brasília, por exemplo, é possível observar uma correlação muito próxima. Não são os pés e as mãos delicados de Michelangelo, tampouco os pés e as mãos fortes e tensos de Auguste Rodin. Os pés e as mãos de Ceschiatti são dramáticos, hiperbólicos, exagerados, como os de Portinari.

Essa mesma característica geometrizada das estátuas A Justiça (DIEHL, 2009) e As três Forças Armadas (Rctk caRIOca, 2011) pode ser observada também na estátua Minerva (JUNIOR; MORENO, 2019b), que Ceschiatti construiu para a UnB. A linguagem concretista, especialmente presente nessas três estátuas, parece estabelecer um diálogo com a relação entre a deusa da Justiça e Minerva, deusa da guerra e da sabedoria. Justiça, guerra e sabedoria unidas pela mesma linguagem concretista. Enquanto As três forças armadas (Rctk caRIOca, 2011) estão no Monumento aos Mortos na Segunda Guerra Mundial, Minerva (JUNIOR; MORENO, 2019b) está na Biblioteca da Universidade de Brasília, que é o lugar do conhecimento e da sabedoria.

Figura 6 - Minerva (1961), de Alfredo Ceschiatti. Biblioteca Central da Universidade de Brasília

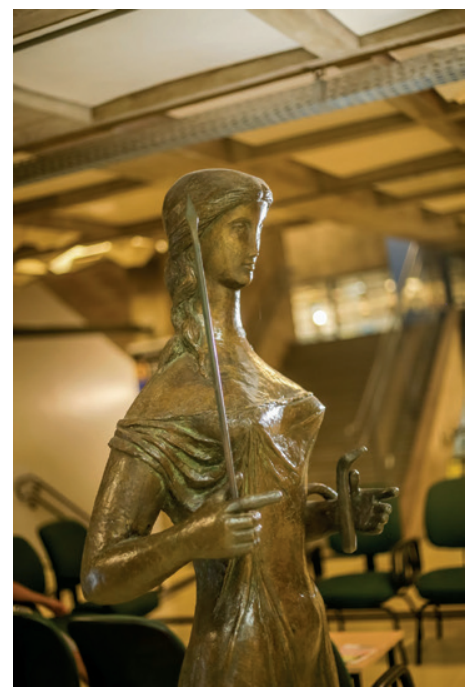

Fonte: JUNIOR, Celso; MORENO, Gustavo. Minerva, na Biblioteca Central da UnB. 1 fotografia. 2019. In: ROSA, Mario. Alfredo Ceschiatti, o escultor dos poderes. GPS Lifetime, 25 ago. 2019. Disponível em: https://gpslifetime. com.br/conteudo/lifestyle/16/alfredo-ceschiatti-o-escultor-dos-poderes. Acesso em: 26 abr. 2021. 
A Justiça (DIEHL, 2009) encontra-se em espaço aberto, enquanto Minerva (JUNIOR; MORENO, 2019b) está em espaço fechado, no interior da Biblioteca da UnB. A justiça pode e deve ser vista por todos, mas a sabedoria exige uma dedicação e um esforço especial de ingresso no interior da biblioteca da Universidade. $A$ Justiça (DIEHL, 2009) está lá para todos, em espaço aberto, ostentando a entrada do STF. Minerva (JUNIOR; MORENO, 2019b) não está disponível para todos indistintamente, mas apenas para aqueles que decidem entrar no espaço do conhecimento que é a biblioteca da universidade.

A Justiça (DIEHL, 2009), com a venda nos olhos, olha para o horizonte, que é o lugar no qual céu e terra se conectam em uma unidade de elementos. A posição da sua cabeça é altiva. Não olha para ninguém em particular. Já Minerva (JUNIOR; MORENO, 2019b), na Biblioteca, tem sua cabeça levemente inclinada para baixo, como se olhasse para a terra à sua frente, simbolizando a sabedoria das universidades. Um olhar individualizado, concreto, verticalizado, diferente do olhar abstrato e horizontal da estátua A Justiça (DIEHL, 2009). Talvez Ceschiatti soubesse que a Justiça, filha de Gaia e Urano, simboliza a unidade entre céu e terra, a unidade entre sabedoria divina e terrena. A posição da sua cabeça está justamente no plano do horizonte, que constitui a unidade entre céu e terra. A deusa Minerva, por outro lado, simboliza uma sabedoria de outro tipo: o saber prático das coisas da terra. Seu olhar é particularizado. Ela olha para a terra, para o chão da Biblioteca da Universidade.

No lugar da lança e do escudo, Minerva (JUNIOR; MORENO, 2019b) segura uma serpente em seu braço esquerdo. Mas não é a mesma serpente que ele usou para simbolizar o pecado original nos painéis da Igreja da Pampulha. É uma serpente diferente. Talvez uma referência aos cabelos da Medusa, a mulher por ela amaldiçoada a petrificar todos que a olhassem nos olhos e que, na mitologia grega, teve sua cabeça decapitada por Perseu. Como presente de Perseu, Minerva colocou a cabeça da Medusa em seu escudo. A Minerva (JUNIOR; MORENO, 2019b) de Ceschiatti não tem o escudo, mas tem a serpente da Medusa. Talvez Ceschiatti esculpiu uma Minerva sem escudo justamente porque ela está em paz dentro da biblioteca, que é o lugar da sabedoria de Minerva, que, sem precisar das armas, transformou as Erínias, deusas da vingança, em Eumênides, deusas da bondade e da produtividade (ÉSQUILO, 1988). 


\section{Justiça sentada ao lado direito de Júpiter}

A imagem da Justiça sentada não é incomum na história da arte. Ela simboliza a relação que a Justiça, na mitologia romana, estabelece com o poder soberano de Júpiter. Como sabemos, Júpiter é o deus dos deuses, o poder soberano absoluto. É o deus que toma as decisões finais. Justiça foi sua esposa e sábia conselheira, que opera um movimento de prudência e moderação do poder soberano de Júpiter. A Justiça sentada, portanto, simboliza a relação entre força e justiça, entre a força do poder soberano de Júpiter e a justiça das leis da Terra.

Júpiter simboliza a personificação do poder soberano: o arquétipo da figura do imperador, rei ou do presidente. A Justiça sentada ao seu lado simboliza a antítese ao poder soberano, como um contrapoder de moderação e prudência. Sentada, a Justiça ocupa seu lugar de conselheira na esfera do poder político. Mas não se trata de uma atitude necessariamente passiva. Pelo contrário, imagens da Justiça sentada, como a da Allegoria del buon governo (ALLEGORIA, [19--?]) de Ambrógio Lorenzetti (1338-1339), revelam a Justiça em plena ação: punindo um criminoso e acalentando a vítima com uma mão (a justiça retributiva) e garantindo a equidade em uma relação comercial com a outra mão (justiça comutativa).

Figura 7 - Detalhe da Allegoria del buon governo (1338-1339), de Ambrogio Lorenzetti

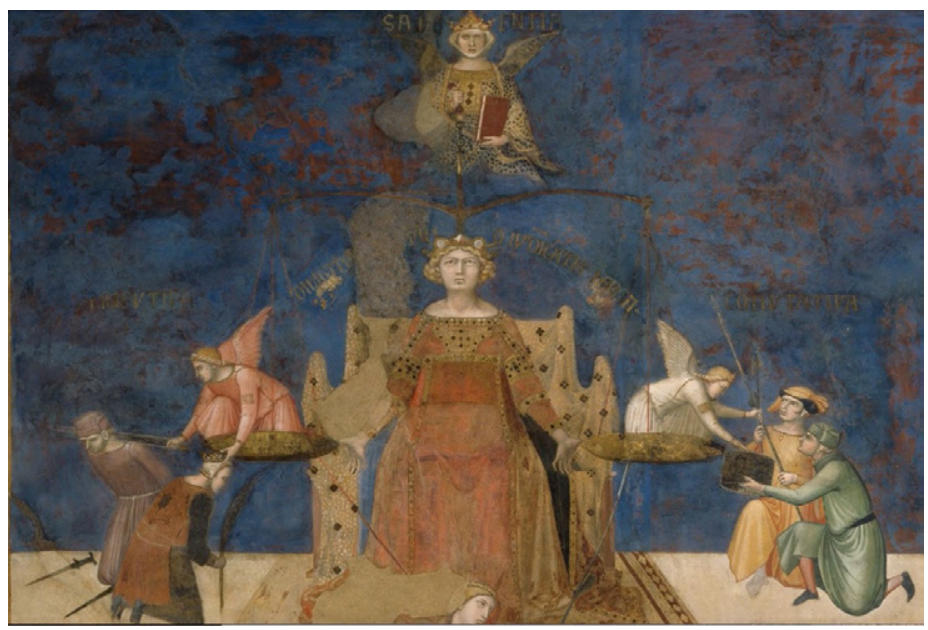

Fonte: ALLEGORIA del buon governo. [19--?]. 1 fotografia. Foto de projetos de arte do Google deixada em domínio público. Disponível em: http://casavacanze.poderesantapia.com/arte/ambrogiolorenzetti/allegoriadelbuongoverno1. htm. Acesso em: 27 abr. 2021. 
Uma referência literária da Justiça sentada pode ser encontrada no Hino Homérico XXIII, para Zeus, de autoria desconhecida, mas hipoteticamente atribuído a Homero:

\author{
Zeus dos Deuses o melhor e o maior cantarei \\ Altitroante regente perfectivo, ele com Justiça \\ que se senta reclinada sólidas conversas confabula. \\ Sê propício, Altitroante Cronida mais glorioso e o maior \\ (HOMERO, 2009).
}

A Justiça sentada, portanto, conecta-se com essa referência mitológica de uma justiça que não age sozinha ou independente de uma relação especial com o poder soberano. É a Justiça sentada ao lado de Júpiter - não acima, tampouco aos seus pés, mas ao lado. A justiça que confabula sólidas conversas com o poder soberano (HOMERO, 2009), que representa a estabilidade, a solidez e cujos resultados, simbolizados pelas filhas da união entre Zeus e Themis, são a equidade, justiça e paz - as Horas; bem como a conexão, a distribuição e o destino - as Moiras (HESÍODO, 2007, p. 151).

Outra Justiça sentada interessante na história da arte é a do frontão da entrada principal do prédio do Palácio da Justiça da Itália, em Roma. Além de sentada, tal como a de Ceschiatti, ela também não possui balança. Com os detalhes e dramatização neoclássicos, a Justiça da Suprema Corte italiana segura, com a mão esquerda, o livro da Lex no lugar da balança. E com a mão direita segura a espada apontada para a terra, simbolizando a relação entre o livro, abstrato, universal, impessoal, imparcial, de um lado, e o poder da força da espada, concreto, prático, individualizado. É a personificação simbólica da noção romana de prudentia - equivalente à grega de phronesis. A relação entre teoria e prática, universal e particular, abstrato e concreto, a lei e a sanção, a justiça e a força do direito. 


\section{Figura 8 - Estátua da Justiça, frontão do Pallazzo di Giustizia, Roma}

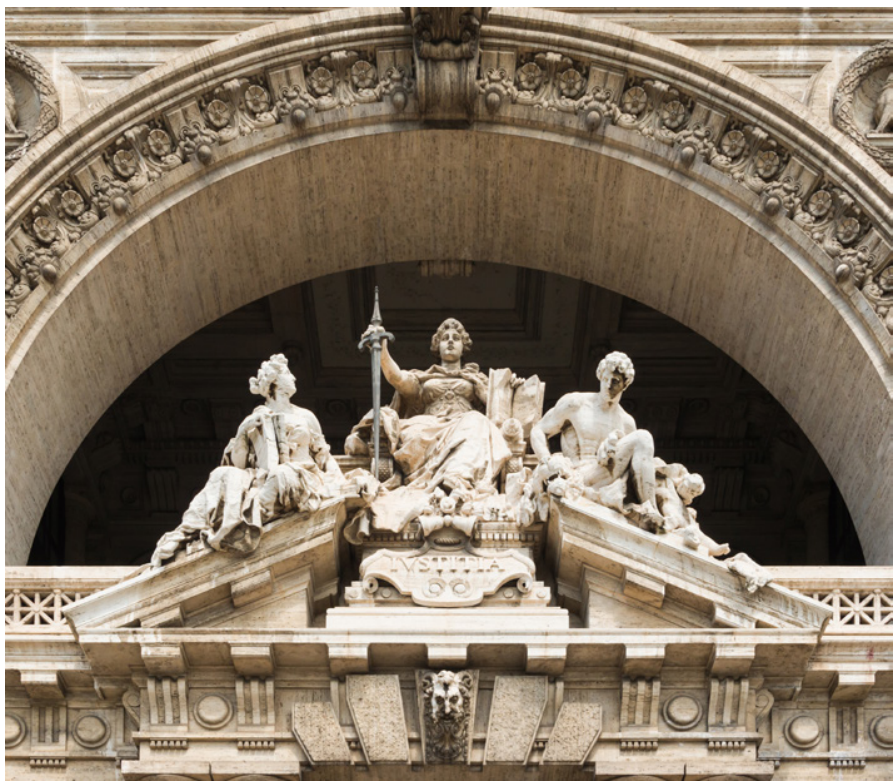

Fonte: JEBULON. Detail of the pediment of the courthouse, Rome, Italy. 2013. 1 fotografia. Disponível em: https://commons.wikimedia.org/wiki/File:Pediment_courthouse,_Rome,_Italy.jpg. Acesso em: 27 abr. 2021.

Essa Justiça não tem olhos vendados. O livro da Lex já simboliza a imparcialidade, abstração, universalidade e impessoalidade da lei escrita. Mas tal como A Justiça (DIEHL, 2009) de Ceschiatti, a Justiça do Pallazzo di Giustizia da Itália não olha para o chão, não olha em nossos olhos. Ela olha para o horizonte, que é o lugar da união entre céu e terra, entre sabedoria divina e terrena, entre a justiça dos deuses e a dos homens.

A Justiça (DIEHL, 2009) de Ceschiatti tem, no entanto, uma singularidade. Ela não está apenas sentada, simbolizando a relação entre ela e o poder soberano de Zeus. Ela está sentada exatamente de frente para a rampa do Palácio do Planalto, que é a sede do governo federal. A posição da estátua em relação ao prédio do STF, à Praça dos Três Poderes e ao Palácio do Planalto foi cuidadosamente calculada. Ela podia estar na frente do STF, no lado ou um pouco mais para a direita, formando uma linha diagonal com o prédio. Mas não. A sua posição assimétrica em relação ao prédio foi cuidadosamente pensada para colocar $A$ Justiça perfeitamente alinhada à rampa da entrada do Palácio do Planalto. Como 
se $A$ Justiça guardasse, sob a proteção de suas mãos, não só a espada da força da potestas soberana, mas também cuidasse de quem sobe a rampa do Planalto portando a auctoritas, cujo símbolo, hoje, é a faixa presidencial, se seus olhos não estivessem vendados.

\section{Justiça cega}

A venda nos olhos da Justiça, hoje, simboliza imparcialidade, abstração, tratamento impessoal dos assuntos do direito. Mas nem sempre foi assim. $\mathrm{Na}$ história da arte, as primeiras representações da Justiça com venda nos olhos surgiram inicialmente como sátira, como crítica à manipulação da justiça pelos advogados (JAY, 1999, p. 19; MANDERSON, 2018, p. 10; RESNIK; CURTIS, 2011, p. 91). A primeira imagem de uma Justiça vendada na história da arte talvez seja esta gravura de Albrecth Dürer, de 1494, publicada na página 71 do livro A nau dos insensatos, de Sebastian Brant (2010, p. 71).

Figura 9 - Das Narrenschiff (1494), de Albrecht Dürer

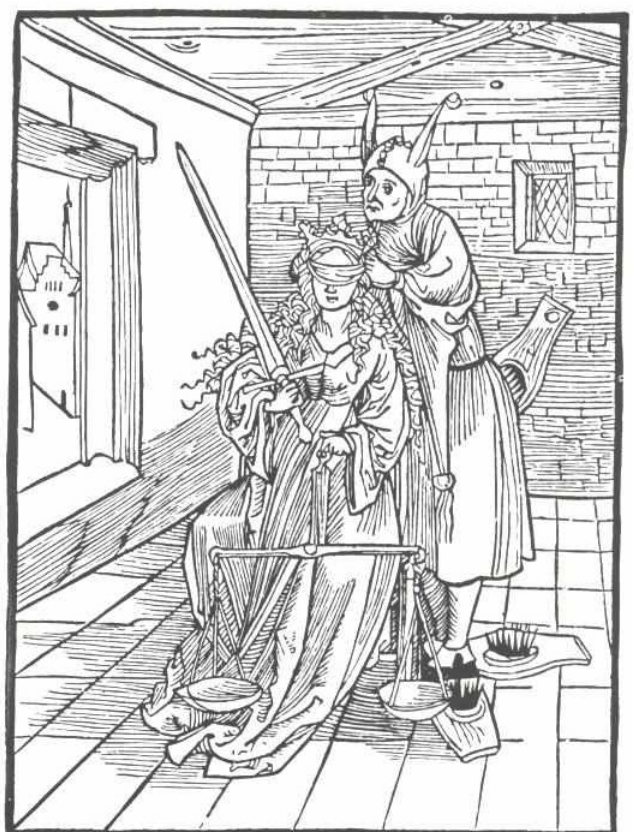

Fonte: DÜRER, Albrecth. Das Narrenschiff. [1494]. 1 gravura. Em domínio público. Disponível em: https://commons.wikimedia.org/wiki/File:D\%C3\%BCrer_-_Das_Narrenschiff_002.jpg? uselang=pt. Acesso em: 27 abr. 2021. 
O mesmo Dürer possui outras gravuras representando a Justiça, mas com os olhos bem abertos, como é o caso da Sol Justiciae, de 1499. A tradição das representações da Justiça na história da arte não é de uma justiça cega, com olhos vendados. Observa-se a imagem da Justiça gravada nas moedas romanas dedicadas à justiça e à imparcialidade, do ano de 77-78 antes de Cristo, época do Imperador Tiberius; ou a Justiça de Lorenzetti (ALLEGORIA..., [19--?]); ou até mesmo, já na modernidade, as Justiças de Reynolds (MANDERSON; MARTINEZ, 2016), Klimt (SIMIONI, 2019) e outras. São todas Justiças com os olhos bem abertos.

Segundo a leitura de Jay (1999, p. 24), a venda nos olhos da Justiça se tornou necessária como símbolo da imparcialidade na modernidade europeia. A urbanização, a secularização e as transformações culturais do início da modernidade tornaram a imagem da Justiça sem venda nos olhos um símbolo do personalismo das formas privadas de justiça do período feudal. A venda nos olhos então simbolizou a transformação do modelo de justiça patrimonialista em uma justiça racional, abstrata, despersonalizada, imparcial e que, assim, pode conferir tratamento igualitário para todos, independentemente das características pessoais ou sociais de cada um ou das preferências políticas, sexuais, religiosas ou morais. A justiça da modernidade deve ser uma justiça imparcial, racional, abstrata, e a venda nos olhos constituiu um modo de simbolizar essa nova característica exigida da justiça moderna.

Mas seja sob o imaginário do liberalismo burguês europeu, seja sob o liberalismo escravocrata brasileiro, a cegueira é uma antítese à liberdade. Então é interessante questionar por que o iluminismo burguês precisou de uma Justiça cega para simbolizar a imparcialidade se a cegueira é uma antítese da liberdade? Enxergar a realidade é uma condição ideal da liberdade. Então que tipo de justiça é essa que não enxerga e como se pode entender o fundamento da liberdade em uma justiça cega?

Adorno e Horkheimer (1985, p. 22-23) sinalizaram que a justiça do esclarecimento, diferente da justiça mitológica do período anterior, utiliza a matemática como seu fundamento. Uma justiça da equivalência, como se pode perceber pela introdução da máxima da proporcionalidade como sinônimo de justiça desde a ponderação de interesses do início do século 20, passando pela ponderação de bens, de valores, até a atual ponderação de princípios. Essa justiça da proporcionalidade rompe com a injustiça da antiga desigualdade entre estratos sociais, mas perpetua aquela injustiça em outro nível: elimina o incomensurável. 
Transforma o caráter pétreo dos direitos fundamentais em relações de precedência condicionada. Os direitos fundamentais deixam de ser compreendidos como fundamentos incondicionais de uma cultura política, para tornarem-se objetivos a serem alcançados na melhor medida possível.

A venda nos olhos da justiça simboliza a imparcialidade e abstração sobre as qualidades pessoais de cada indivíduo, mas significa também a indiferença sobre as desigualdades entre os indivíduos. Não se trata apenas do distanciamento entre sujeito e objeto, tal como o distanciamento entre proprietário e objeto da propriedade: a justiça vendada pode ser comutada, trocada, vendida. Pode inclusive ser excepcionada por razões de Estado, de segurança nacional, de saída da crise econômica, de reserva do possível ou outras formas de exceção.

Estar cego não é tão diferente de estar surdo. Ulisses não obstruiu seus ouvidos para evitar o perigoso canto das sereias (HOMERO, 2014, p. 373). Também não mudou o curso do seu navio para desviar-se de sua rota. Reconheceu sua pequenez, falibilidade e limitações. Amarrou-se prisioneiro ao próprio navio e ordenou que seus marinheiros não seguissem suas ordens. Ulisses, assim, conseguiu evitar o perigo mortal do canto das sereias, sem desviar sua rota. E fez isso sem tampar seus ouvidos, porque a autonomia do destino do seu navio pressupôs não a supressão dos sentidos afetados pelo perigo, mas o reconhecimento da falibilidade do soberano e seu recolhimento, ainda que por um período provisório, em uma esfera não soberana do seu navio.

Tal como Ulisses, também a Justiça não precisa de olhos vendados para tornar-se imparcial, abstrata, insuscetível aos encantos - e pressões - da política e da economia. Mais importante que a imparcialidade é a autonomia. A capacidade de fazer justiça com independência em relação às exigências da política e da economia. A Justiça sentada ao lado de Júpiter simboliza essa autonomia. A venda em seus olhos foi uma exigência típica do iluminismo burguês europeu, que não faz o menor sentido para países colonizados e com índices brutais de desigualdades sociais como o Brasil.

Mas ela tem, por outro lado, a misteriosa ambivalência de poder simbolizar, também, uma antítese ao patrimonialismo. Se entendermos a venda nos olhos da Justiça como antítese ao patrimonialismo, contra o "liberalismo escravocrata" do século 19 e seus equivalentes discursivos hoje, então há bons motivos para mantê-la cega. Outra possível interpretação da venda nos olhos da Justiça é entendê-la 
como um modo de não vermos seu rosto. Um modo de simbolizar a justiça como instituição, organização, como um espaço político despersonalizado.

Seguindo a linguagem da arte concretista dos anos de 1960, que valorizava a participação do observador na obra, preferimos interpretar a venda nos olhos da Justiça como um recado especial para nós, profissionais do direito: a justiça está cega para nos lembrar de estarmos sempre atentos, com nossos olhos bem abertos. Como Ulisses diante da sedução do canto das sereias, devemos estar com os olhos e ouvidos atentos, e reconhecer nossa pequenez, nossa falibilidade, nossa fragilidade diante do canto das sereias. A justiça está cega para nos lembrar da nossa responsabilidade, como profissionais do direito, de abrirmos nossos olhos.

\section{Espada sem sombras}

Com as duas mãos, A Justiça (DIEHL, 2009) de Ceschiatti segura o cabo e a ponta da espada confortavelmente repousada em seu colo. Com uma mão voltada para a terra e outra para o céu, as mãos da estátua $A$ Justiça simbolizam a conexão entre a justiça dos homens e a divina. Mas a espada, deitada em seu colo, designa uma inoperosidade ${ }^{4}$ desconcertante para uma imagem da justiça.

As justiças iluministas geralmente são representadas por Justiças retratadas em ambientes ensolarados e arejados, com espada bramida em uma mão, balança na outra e os pés subjugando as trevas e o crime. A espada da estátua A Justiça (DIEHL, 2009) de Ceschiatti, por outro lado, não tem sombra. Não porque não está em um espaço arejado e iluminado, mas porque ela está no colo da Justiça.

Sob um primeiro olhar iluminista, a espada no colo poderia simbolizar um momento de descanso, entre um e outro julgamento. Mas essa interpretação não revela a surpreendente potencialidade de sentido que Ceschiatti preparou para a cultura jurídica brasileira: a espada em seu colo não está lá descansando. Está guardada, protegida, cuidada. A espada da Justiça não é exatamente da justiça. É a espada da potestas do poder soberano. Ela simboliza a força, a violência soberana. A Justiça (DIEHL, 2009) de Ceschiatti é uma justiça guardiã não só da

\footnotetext{
${ }^{4}$ Inoperosidade é um conceito quem vem do désoeuvrement de Blanchot (1968, p, 29, 39 e ss) e retomada por Nancy no seu livro La communaute désoeuvrée (1999). Mas Agamben (2007) coloca esse conceito no centro da sua análise genealógica do poder. Para ele, inoperosidade não significa inércia, omissão, mas katargesis, isto é, uma operação na qual o como substitui o que. A lei que se aplica desaplicando-se é uma ilustração da inoperosidade do direito. Nem ato, tampouco potência, mas o limiar entre ato e potência.
} 
Constituição, mas também da potestas do poder soberano, da força da máquina administrativa que, no Estado moderno, chamamos de Poder Executivo.

Tal como a representação do Gênesis no ambiente do batistério da Igreja da Pampulha, também a estátua A Justiça (DIEHL, 2009) de Ceschiatti provoca um desconcertante e surpreendente deslocamento de sentido ao oferecer a imagem da inoperosidade da força do direito. Do mesmo modo como o batistério da Igreja da Pampulha esperava a iconografia da cena bíblica de São João Batista batizando Jesus, também o prédio do STF esperava uma estátua A Justiça (DIEHL, 2009) com a espada em ato ou em potência, para glorificar a força do direito da Corte Constitucional, para celebrar a eficácia da norma jurídica no Brasil e para aclamar a potência do poder soberano, não só de dizer, mas também de fazer acontecer, a última palavra sobre o direito do País.

A inoperosidade da força do direito que a espada guardada no colo da Justiça propicia produz uma potência de significados surpreendentes, os quais podemos organizar, didaticamente, em duas diferentes camadas de significação: a) em uma dimensão temporal, a inoperosidade do poder como momento de reflexão da Justiça; e b) em uma dimensão objetiva, a inoperosidade do poder como consubstancialização da relação entre justiça e força.

a) Entre a imagem de uma Justiça ativa, militante, engajada nas questões sociais do país ou uma justiça passiva, omissa, indiferente ou descomprometida com os princípios e valores que ela representa, a estátua $A$ Justiça (DIEHL, 2009) de Ceschiatti não está em nenhum desses dois polos de significação. A espada em seu colo não significa nenhuma glorificação da força soberana do direito, mas também não significa a tola imagem de uma deusa omissa, passiva, alienada, indiferente ou distante da realidade brasileira. Ela significa a inoperosidade do poder, isto é, o momento em que a tensão histórica entre força e justiça encontra um ponto de reflexão. É o tempo no qual a dinâmica força soberana de Júpiter e a estável sabedoria da Justiça se encontram. É um retrato do momento especial em que, sentada ao lado de Júpiter, a Justiça com ele "sólidas conversas confabula" (HOMERO, 2009).

Em um mundo dominado pela técnica e pelo fazer instrumental, os momentos de contemplação e reflexão tornam-se momentos genuínos, singulares, especiais. A espada no colo da estátua simboliza essa rara temporalidade em que a Justiça desacelera para pensar, refletir, julgar seus próprios critérios, ouvir e aconselhar. Contemplação e reflexão - ou, utilizando a linguagem da política da governamentalidade: escutar e planejar - são características da sabedoria. 
Decidir não é só um agir. É também um observar, refletir, pensar. Não é uma justiça ativista ou passivista, é a justiça no exato momento do limiar entre ação e omissão, entre jus e actio, entre saber e fazer.

Como a poesia é o momento da inoperosidade da linguagem, a Justiça com a espada no colo é o momento da inoperosidade da força do direito. A linguagem constrói mundos, informa, produz comunicação. A poesia suspende por um instante esses fazeres da linguagem. Assim como a espada no colo da estátua $A$ Justiça (DIEHL, 2009) de Ceschiatti, a poesia em relação à linguagem também não é uma omissão. É um momento de liberdade da violência da forma da função, do instrumento, do meio para alguma finalidade. A poesia é o momento no qual a linguagem se liberta das suas funções de meio operantes para tornar-se ela própria um ser. É o momento de reflexão. Do mesmo modo que a poesia em relação à linguagem, a espada no colo da Justiça significa o instante especial de libertação da justiça em relação à força. É o momento em que a justiça não precisa da força da sanção soberana, porque ela é a força.

b) Se a espada no colo da Justiça pode significar, em uma primeira camada de significação, o momento temporal da inoperosidade da força, em uma segunda camada de significação ela também pode significar a unidade objetiva da diferença entre força e justiça. Do mesmo modo que, na mitologia egípcia, a deusa Maat não representava a justiça, mas ela própria era a justiça; como nas mitologias gregas e romanas as divindades não representavam habilidades, mas elas próprias eram a personificação das suas habilidades, também a espada no colo da Justiça não representa apenas um momento excepcional em que ato e potência se encontram, mas sobretudo constitui um limiar de indistinção entre força e justiça, dentro do qual elas se tornam uma unidade.

A tensão histórica entre força do direito e justiça do direito, que está na base da construção do Estado moderno desde Hobbes e Pascal, ganha um novo significado quando olhamos para A Justiça (DIEHL, 2009) de Ceschiatti com a espada descansando em seu colo, porque agora talvez possamos entender que não se trata, exatamente, da espada da Justiça, mas sim da espada que simboliza a força e a violência do poder soberano. É o símbolo da potestas, do poder soberano sobre a vida e morte dos seus súditos. Ceschiatti retirou a espada das mãos do governo e a colocou no colo da Justiça. A Justiça do STF, assim, tornou-se guardiã não só da Constituição, mas também da força e da violência soberana do governo. 
Figura 10 - Justice (1988), High Court of Zambia, Lusaka, Zâmbia

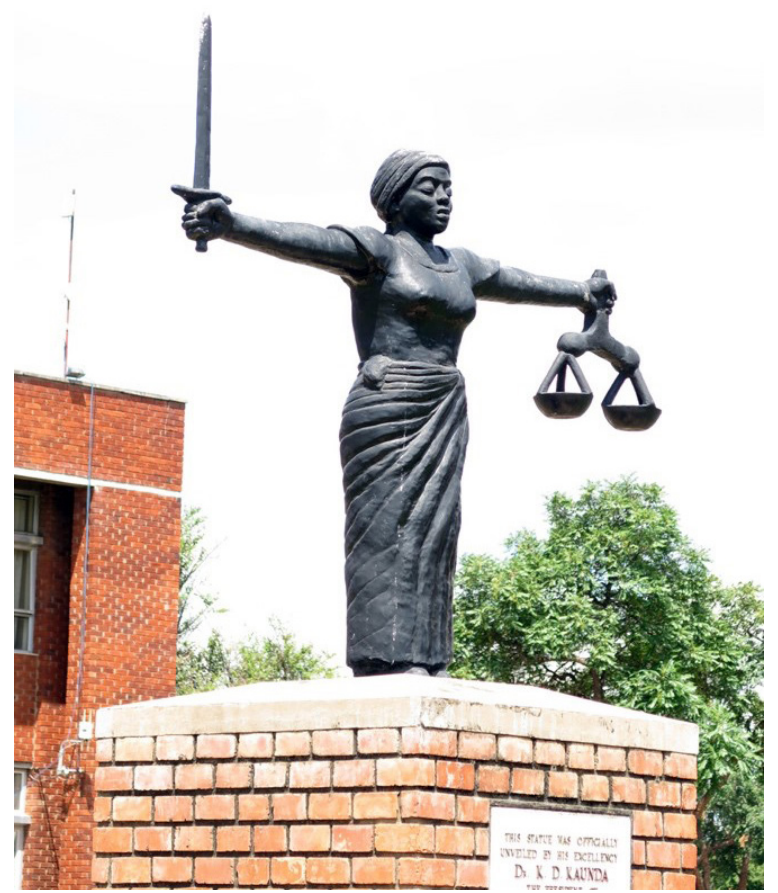

Fonte:JUSTICE. 2013. 1 fotografia. Disponível em: https://thewanderingscot.com/photos/2013\%20Africa/Zambia/ midis/IMG_0655.jpg. Acesso em: 27 abr. 2021.

A imagem da Justiça da Hight Court da Zâmbia (JUSTICE, 2013) transmite um significado de uma justiça militante, socialmente comprometida e consciente dos desafios presentes na história daquele país. É uma Justiça consciente da tensão histórica entre violência da força e justiça. A Justiça (DIEHL, 2009) de Ceschiatti é diferente. É uma Justiça diante da qual força e justiça se encontram em uma relação de unidade originária. Talvez por isso ela nem precise da balança. Não precisa mais de símbolos que representem o equilíbrio ou a equivalência, porque ela é o equilíbrio ou a equivalência. Tal como a estátua da Justiça da Suprema Corte do Canadá (ROBERTSON, 2010), de 1946, A Justiça (DIEHL, 2009) do STF também não precisa da balança, porque a espada da potestas do poder soberano está devidamente guardada e protegida em seus braços. 
Figura 11 - Justice (1946), de Walter Seymour Allward. Supreme Court of Canada, Ottawa, Canadá

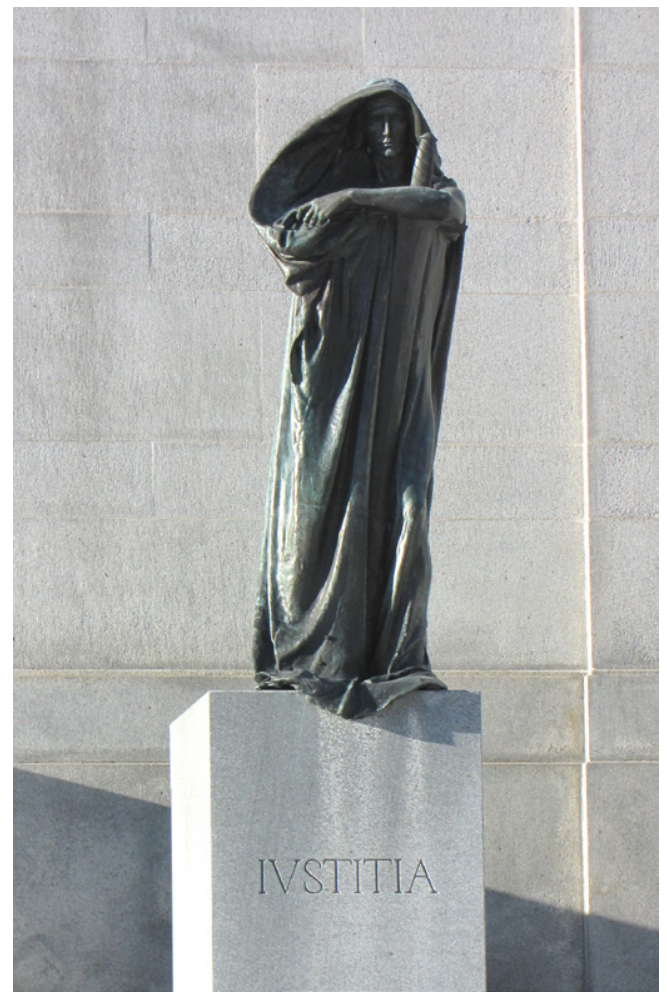

Fonte: ROBERTSON, D. Gordon E. Statue of Justicia (Justice): by Walter Seymour Allward, outside Supreme Court of Canada, Ottawa, Ontario, Canada. 2010. 1 fotografia. Disponível em: https://commons.wikimedia.org/wiki/ File:Justicia_Ottawa.jpg. Acesso em: 27 abr. 2021.

A espada no colo da Justiça poderia simbolizar o direito como mediação da tensão entre facticidade e validade que, por ser fruto do consenso sob condições ideais de comunicação, sua legitimidade e realização prescindem da força. Poderia também simbolizar as concepções substancialistas de direito como experiências histórico-materiais inscritas na comunidade da qual fazemos parte. Outras leituras da espada guardada no colo são possíveis, mas nenhuma delas capta essa estranha sensação de inoperatividade, que não é nem uma ação, tampouco uma omissão. Nem ativismo, mas também não se trata de passivismo, indiferença, alienação. A inoperosidade da espada da Justiça revela justamente o limiar entre a força e a correção do direito. 
Como a imagem simbólica da glória do trono vazio do soberano (AGAMBEN, 2007, p. 268), a espada inoperante nos fala de uma justiça que não se limita a dicere o direito, mas que o faz acontecer. Uma justiça que não separa a palavra do acontecimento, porque sua palavra é um fazer. Não segrega o ato de dizer o direito do agir para a realização do direito, mas que, ao dizer, realiza-o, porque a justiça não pode ser apenas um símbolo que representa uma ideia, um conceito ou uma expectativa, mas, sim, um saber-fazer, um conhecimento que faz, que transforma.

A espada no colo da Justiça, segundo nossa leitura, promove uma ruptura com a expectativa política de glorificação do poder soberano. Ela quebra os protocolos, subverte os cerimoniais, profana as liturgias políticas e nega a aclamação da glória para a força soberana. A espada no colo frustra a expectativa política de glorificação do poder, porque o poder, nessa perspectiva, já não está mais nem na auctoritas, tampouco na potestas, mas guardada no colo e sob a proteção das mãos da justiça. No Brasil, a espada que simboliza a força do poder soberano está devidamente guardada no colo da estátua A Justiça (DIEHL, 2009) do STF.

A Justiça (DIEHL, 2009) de Ceschiatti sugere que o STF não é guardião apenas da Constituição, mas também da força e violência da máquina administrativa do poder soberano. Guardar a espada da sanção soberana no colo simboliza

a belíssima prestação da Justiça para Júpiter, que foi a de torná-lo correto, sólido e inquestionável. Ceschiatti desloca a violência do Estado e a coloca no colo da Justiça. A espada, que simboliza a potestas do soberano - o poder de vida e de morte do soberano sobre seus súditos -, não está nas mãos do governo, mas protegida, no colo, pelas mãos da Justiça.

\section{O vazio da balança}

Uma razão puramente técnica da escultura poderia indicar o motivo pelo qual Ceschiatti não esculpiu a balança da estátua A Justiça (DIEHL, 2009). O material utilizado e a área externa tornam difícil e arriscado esculpir uma balança em bloco maciço de granito. Talvez nem fosse possível esculpir uma estátua em pé em granito, porque ela quebraria. Imagine-se, então, os detalhes finos de uma balança. As limitações do material utilizado podem ter interferido na decisão do artista por apresentar A Justiça (DIEHL, 2009) sentada e sem balança. Uma estratégia estética minimalista, muito bem aceita pelo movimento artístico da época. Mas essa hipótese não é uma boa interpretação da obra. Ceschiatti fez a 
espada em granito. Ele poderia, se quisesse, fazer a balança também. Estilizada, geometrizada ou entalhada, existiriam várias possibilidades de fazer a balança sem comprometer a integridade do monobloco de granito maciço e sem acumular água da chuva ou resíduos de poluição.

Segundo nossa leitura, a falta da balança da Justiça pode ser um diálogo com a falta de Golias na estátua de Davi, de Michelangelo. Ela indica uma outra temporalidade da justiça. É o momento anterior à realização da justiça, como o Davi de Michelangelo representa o momento anterior à batalha com Golias. A falta de balança significa que a justiça no Brasil ainda está para ser feita. E talvez essa mensagem, na forma de um monumento artístico, possa significar que a justiça sempre está para ser feita, como a batalha de Davi, que representa nossas batalhas cotidianas: derrubar um Golias todos os dias. O vazio da balança na estátua A Justiça (DIEHL, 2009) de Ceschiatti simboliza a justiça como devir, como uma prática cotidiana que deve ser constantemente renovada e reafirmada em nossa vida política cotidiana.

Interessante observar que as imagens de balanças, desde Maat, do Egito antigo, até as de São Miguel e da justiça do bom governo de Lorenzetti (ALLEGORIA..., [19--?]), possuem elementos em seus pratos. Não são balanças vazias, abstratas, formais. São balanças nas quais se pesam almas, corações, objetos simbólicos. As imagens da Justiça a partir do renascentismo esvaziaram o conteúdo dos pratos da balança. A formalização da imagem da balança vazia corresponde perfeitamente à formalização do direito moderno, que, centrado nos textos, desconectou-se de sua fundamentação moral, ética e de justiça. A balança vazia é o símbolo do formalismo jurídico da modernidade europeia.

A Justiça (DIEHL, 2009) de Ceschiatti nos ajuda a pensar nessa questão do formalismo do direito moderno, cujo correlato visual é a balança vazia, a balança sem télos, sem finalidade definida. Heidegger (1995, p. 14) nos lembra que, na Grécia antiga, a noção de finalidade presente na expressão télos era bastante diferente da noção de objetivo a ser alcançado. Objetivo a ser alcançado é aquilo que, quando atingido, dá-se por completo e se encerra. Finalidade é objetivo, mas também é plenitude. Diferente dos objetivos, a finalidade só se alcança quando se consegue realizá-la em sua plenitude. Na tradição hebraico-cristã, a noção de justiça é messiânica (SIMIONI, 2018, p. 151). Uma justiça que, em um só ato, resolve todas as injustiças do mundo. É o contrário de uma justiça, como podemos dizer, "levítica", que nunca se realiza em sua plenitude, porque 
só se realiza por meio da simplicidade dos pequenos sacrifícios e das atitudes cotidianas que cada um de nós é convidado a realizar todos os dias.

O Davi de Michelangelo também simboliza nossa batalha cotidiana, nosso enfrentamento de um Golias por dia. Não é o Davi vitorioso, realizado porque derrotou Golias. É o Davi antes da batalha, com a verdade exposta do seu corpo nu, caminhando em direção à Golias. A Justiça (DIEHL, 2009) de Ceschiatti também não é a justiça do malhete do magistrado, cuja martelada dá por encerrada a sessão de julgamento. É a justiça antes da sua realização. Mas por que ela está sem balança? Porque a balança está em nós. Diferente da noção messiânica da justiça divina, que em um só ato realiza toda a justiça para o mundo, A Justiça (DIEHL, 2009) de Ceschiatti simboliza a justiça que nós - e não os deuses - devemos fazer. Simboliza a responsabilidade que nós temos de, por meio de pequenos sacrifícios diários, simples gestos e, por vezes, grandes renúncias, fazer a justiça nos pequenos atos de nossa vida cotidiana.

Entre balanças vazias e o vazio da balança, Ceschiatti nos oferece um presente especial: a balança não está com a Justiça porque ela está em nós - em mim, em você e em todos nós. Quando olhamos para uma obra de arte, também olhamos para nós mesmos. Quando olhamos para A Justiça (DIEHL, 2009) de Ceschiatti sem balança, olhamos para nós mesmos. A balança não está com ela porque está em nossas mãos.

A arte também é uma forma de espelho, no qual olhamos para nossa história e para nós mesmos. A Justiça (DIEHL, 2009) de Ceschiatti não esqueceu a balança. Ela a entregou para nós, como um presente, para que possamos fazer justiça nessa encruzilhada histórica entre a reprodução de um passado de desigualdades sociais e um futuro aberto a novas possibilidades.

\section{Conclusão}

Ceschiatti faleceu em 25/8/1989. Filho de padeiro em Minas Gerais, ele seguiu a profissão do pai. No entanto, em vez de mexer na massa do pão, ele mexeu na massa de estátuas. As estátuas de bronze são como pães; é preciso somar e modelar a massa para que ela conquiste a sua forma. Já as estátuas de granito, como é o caso da estátua A Justiça (DIEHL, 2009), precisam ser subtraídas e destruídas para que conquistem sua forma. Curiosamente, as Duas amigas (DUAS..., [19--?]) do Palácio do Itamaraty, Minerva (JUNIOR; MORENO, 2019b) 
da UnB e As Iaras (AS IARAS, [19--?]) do Palácio da Alvorada são de bronze. A Justiça (DIEHL, 2009) é de granito.

Justiça como desconstrução nos lembra Jacques Derrida, segundo o qual ela é, precisamente, a desconstrução do direito (DERRIDA, 2007, p. 27). É, para falar a língua do outro, romper com a minha própria língua (DERRIDA, 2007, p. 29). Ceschiatti foi um desconstrutor do direito no Brasil. De um bloco maciço, unitário e hegemônico da história geológica do solo de Petrópolis, ele desconstruiu a história geológica para transformá-la em uma história geopolítica. Não a política dos territórios geográficos, mas a dos espaços simbólicos. Desconstruiu a pesada pedra de granito jurídico da história do Brasil, para encontrar a forma da justiça.

Não se trata de uma estátua meramente decorativa do STF, tampouco de uma imagem política para glorificar e legitimar o regime de poder do desenvolvimentismo da época. As obras de Ceschiatti são rebeldes, inteligentes, surpreendentes. Essa rebeldia das ausências e presenças, das localizações e dos deslocamentos, das utopias e das heterotopias talvez seja a assinatura de Ceschiatti em toda sua produção artística.

No lugar da figura agressiva e masculinizada do governo executivo, Ceschiatti colocou, no Palácio da Alvorada, duas mulheres tomando banho, confortáveis, seguras, confiantes e, ao mesmo tempo, fraternas, pois a posição dos seus gestos em rapport designa uma relação intimista entre as elas. No Palácio do Itamaraty, em vez da reprodução da simbologia pitoresca da imagem do Brasil no exterior, Ceschiatti colocou Duas amigas (DUAS..., [19--?]), barrocas, fornidas, em um abraço afetuoso diante do qual se pode encontrar o sentido da diplomacia internacional, que é o da cooperação, da amizade, da parceria para um grande projeto político comum. No Teatro Nacional, uma contorcionista circense da arte do povo, e, na UnB, uma Minerva (JUNIOR; MORENO, 2019b) sem escudo e capacete de guerreira, como se ali, no lugar do conhecimento, ela pudesse encontrar finalmente a sabedoria para promover a paz.

No STF, em vez de uma deusa glamorosa com espada e balança à mão, Ceschiatti apresenta uma Justiça sentada, sem balança e com a espada guardada no colo. Justiça concretista, geometrizada, nem humana, tampouco deusa. Sentada, ela simboliza o diálogo entre justiça e poder soberano. É a Justiça sentada ao lado de Júpiter. A justiça lado a lado com o governo. A espada no colo simboliza a guarda do poder da força e violência do soberano. A justiça do STF 
não guarda apenas a Constituição, ela guarda também a espada do Estado. A balança não está com ela porque está conosco - comigo, com você e com todos nós. Como um presente especial, a balança da justiça, em nossas mãos, não está vazia como a das justiças do iluminismo europeu: ela está cheia daquilo que nós acreditamos ser importante para o futuro do direito no Brasil. Seus olhos vendados não significam apenas imparcialidade e abstração, mas uma antítese ao patrimonialismo, ao clientelismo e ao caudilhismo das culturas coloniais latino-americanas.

A Justiça (DIEHL, 2009) de Ceschiatti olha para o horizonte, que é o lugar onde a sabedoria divina se conecta com a sabedoria terrena. Na direção de seu olhar está, exatamente, a rampa do Palácio do Planalto, que é a sede do Governo Executivo do Brasil. Seu olhar, contudo, não é um olhar de glorificação ou de aclamação do poder. Sentada, com a espada devidamente guardada no colo e protegida por suas mãos, é a Justiça da autonomia.

\section{Referências}

AS IARAS. [19--?]. 1 fotografia. Disponível em: https://pt.m.wikipedia.org/ wiki/Ficheiro:Obra_\%22As_Iaras\%22_de_Alfredo_Ceschiatti.jpg. Acesso em: 26 abr. 2021.

O ABRAÇO. In: ENCICLOPÉDIA Itaú Cultural de Arte e Cultura Brasileiras. São Paulo: Itaú Cultural, 2021. Disponível em: http://enciclopedia.itaucultural. org.br/obra15114/o-abraco. Acesso em: 26 abr. 2021. Verbete da Enciclopédia.

ADORNO, Theodor W.; HORKHEIMER, Max. Dialética do esclarecimento: fragmentos filosóficos. Tradução de Guido Antonio de Almeida. Rio de Janeiro: Jorge Zahar Editor, 1985.

AGAMBEN, Giorgio. Il regno e la gloria: per una genealogia teologica dell'economia e del governo. Vicenza: Neri Pozza, 2007.

ALLEGORIA del buon governo. [19--?]. 1 fotografia. Foto de projetos de arte do Google deixada em domínio público. Disponível em: http://casavacanze. poderesantapia.com/arte/ambrogiolorenzetti/allegoriadelbuongoverno1.htm. Acesso em: 27 abr. 2021. 
ALLWARD, Walter Seymour. Justice. 1946. Supreme Court of Canada. Fotografia de D. Gordon E. Robertson, 2010.

BLANCHOT, Maurice. L'espace littéraire. Paris: Gallimard, 1968.

BRANT, Sebastian. A nau dos insensatos. Tradução de Karin Volobuef. São Paulo: Octavo, 2010.

BRITO, Mário da Silva. História do modernismo brasileiro I: antecedentes da Semana de Arte Moderna. Rio de Janeiro: Civilização Brasileira, 1971.

DERRIDA, Jacques. Força de lei: o fundamento místico da autoridade. Tradução de Leyla Perrone-Moisés. São Paulo: Martins Fontes, 2007.

DIDI-HUBERMAN, Georges. A imagem sobrevivente: história da arte e do tempo dos fantasmas segundo Aby Warburg. Tradução de Vera Ribeiro. Rio de Janeiro: Contraponto, 2013.

DIEHL, Jorge. A Justiça. 2009. 1 fotografia. Acervo pessoal do artista. Publicação com autorização do artista.

DUAS amigas. [19--?]. 1 fotografia. Disponível em: https://www.gov.br/mre/ pt-br/media/dsc0113-dammer.jpg/view. Acesso em: 26 abr. 2021.

DÜRER, Albrecht. Das Narrenschiff. 1494. 1 gravura, Beinecke Rare Book and Manuscript Library, Yale University.

ÉSQUILO. A trilogia de Orestes. Tradução de David Jardim Júnior. São Paulo: Ediouro, 1988.

FABRIS, Annateresa. Modernidade e vanguarda: o caso brasileiro. In: FABRIS, Annateresa. (org.). Modernidade e modernismo no Brasil. Campinas: Mercado de Letras, 1994, p. 9-25.

GUEDES, Gisele; VIVAS, Rodrigo. Tradição e diálogo: análise do baixo-relevo da Igreja de São Francisco de Assis. In: ANAIS do 25 Encontro da ANPAP: arte: seus espaços e/em nosso tempo. Porto Alegre, 2016, p. 914-929.

HEIDEGGER, Martin. La pregunta por la técnica. In: HEIDEGGER, Martin. Conferencias y artículos. Tradução de Eustaquio Barjau. São Paulo: Odós, 1995, p. 9-37. 
HESÍODO. Teogonia: a origem dos deuses. Tradução Jaa Torrano. São Paulo: Iluminuras, 2007.

UMA HOMENAGEM ao patriarca. Folha de São Paulo, São Paulo, 6 set. 1972.

HOMERO. Hino Homérico XXIII - a Zeus. Tradução de Rafael Brunhara. 2009. Disponível em: http://primeiros-escritos.blogspot.com/2009/08/hinohomerico-xxiii-zeus.html?m=1. Acesso em: 29 out. 2020.

HOMERO. Odisseia. Tradução de Christian Werner. São Paulo: Cosasc Naify, 2014.

JAY, Martin. Must justice be blind?: the challenge of images to the law. In: DOUZINAS, Costas; NEAD, Lynda (org.). Law and the image: the authority of art and the aesthetics of law. Chicago: Londres: University of Chicago Press, 1999, p. 19-35.

JEBULON. Detail of the pediment of the courthouse, Rome, Italy. 2013. 1 fotografia. Disponível em: https://commons.wikimedia.org/wiki/File:Pediment_ courthouse,_Rome,_Italy.jpg. Acesso em: 27 abr. 2021.

JUNIOR, Celso; MORENO, Gustavo. Os Evangelistas, na entrada da Catedral Metropolitana de Brasília. 1 fotografia. 2019a. In: ROSA, Mario. Alfredo Ceschiatti, o escultor dos poderes. GPS Lifetime, 25 ago. 2019. Disponível em: https:/gpslifetime.com.br/conteudo/lifestyle/16/alfredo-ceschiatti-o-escultordos-poderes. Acesso em: 26 abr. 2021.

JUNIOR, Celso; MORENO, Gustavo. Minerva, na Biblioteca Central da UnB. 1 fotografia. 2019b. In: ROSA, Mario. Alfredo Ceschiatti, o escultor dos poderes. GPS Lifetime, 25 ago. 2019. Disponível em: https://gpslifetime.com.br/conteudo/ lifestyle/16/alfredo-ceschiatti-o-escultor-dos-poderes. Acesso em: 26 abr. 2021.

JUSTICE. 2013. 1 fotografia. Disponível em: https://thewanderingscot.com/ photos/2013\%20Africa/Zambia/midis/IMG_0655.jpg. Acesso em: 27 abr. 2021.

LUHMANN, Niklas. El arte de la sociedad. Tradução de Javier Torres Nafarrate. México: Herder Editorial: Universidad Iberoamericana, 2005.

MANDERSON, Desmond. Blindness visible: law, time and bruegel's justice. ANU College of Law: Legal Studies Research Paper Series, n. 18.1, p. 2-20, 2018.

MANDERSON, Desmond; MARTINEZ, Cristina S. Justice and art, face to face. Yale Journal of Law \& the Humanities, v. 28, n. 2, p. 241-263, 2016. 
MÃOS na massa: entrevista de Alfredo Ceschiatti. Veja, n. 401, p. 106-108, 12 maio 1976.

MUSA, João. O lavrador de café. [19--?]. 1 fotografia. Disponível em: https:// masp.org.br/acervo/obra/o-lavrador-de-cafe. Acesso em: 26 abr. 2021.

NANCY, Jean-Luc. La communaute désoeuvrée. Paris: Christian Bourgois, 1999.

Rctk CaRIOca. As três Forças Armadas. 2011. 1 fotografia. Reprodução com autorização do autor.

RESNIK, Judith; CURTIS, Dennis. Representing justice: invention, controversy, and rights in city-states and democratic courtrooms. New Haven: London: Yale University Press, 2011.

ROBERTSON, D. Gordon E. Statue of Justicia (Justice): by Walter Seymour Allward, outside Supreme Court of Canada, Ottawa, Ontario, Canada. 2010. 1 fotografia. Disponível em: https://commons.wikimedia.org/wiki/File:Justicia_ Ottawa.jpg. Acesso em: 27 abr. 2021.

SILVA, João Balbino. Alfredo Ceschiatti na Catedral Metropolitana de Brasília: o valor da forma. Dissertação (Mestrado em Arte). Instituto de Artes. Universidade de Brasília, Brasília, 2019.

SIMIONI, Ana Paula Cavalcanti. Modernismo no Brasil: campo de disputas. In: BARCINSKY, Fabiana Werneck (org.). Sobre a arte brasileira: da pré-história aos anos 1960. São Paulo: Martins Fontes, 2014, p. 232-263.

SIMIONI, Rafael Lazzarotto. A Jurisprudenz de Gustav Klimt: direito, esfera pública e violência soberana. Anamorphosis: Revista Internacional de Direito e Literatura. v. 5, n. 1, p. 37-68, jan./jun, 2019.

SIMIONI, Rafael Lazzarotto. Opus operatum e opus operantis: quando a validade do direito se desconecta da virtude de quem o aplica. Estudos de Religião, v. 32, n. 2, p. 139-161, maio/ago. 2018.

WARBURG, Aby. A renovação da antiguidade pagã: contribuições científicoculturais para a história do Renascimento europeu. Tradução de Markus Heidiger. Rio de Janeiro: Contraponto: Museu de Arte do Rio, 2013. 